\title{
Correction: CpG island hypermethylation-associated silencing of non-coding RNAs transcribed from ultraconserved regions in human cancer
}

\author{
A. Lujambio ${ }^{1} \cdot$ A. Portela ${ }^{1} \cdot$ J. Liz $^{1} \cdot$ S. A. Melo ${ }^{1} \cdot$ S. Rossi ${ }^{2} \cdot$ R. Spizzo ${ }^{2} \cdot$ C. M. Croce ${ }^{3} \cdot$ G. A. Calin ${ }^{2} \cdot$ M. Esteller $^{1,4}$ \\ Published online: 5 November 2018 \\ (c) The Author(s) 2018. This article is published with open access
}

Correction to: Oncogene; https://doi.org/10.1038/onc.2010. 361; published online 30 August 2010

In the original article the authors have noted that the wrong image was used to illustrate the Uc.346 + Lu1-Lu2Lu3 subpanel of Figure 5a. The correct image is now provided as Figure 1 in this article. This change does not affect the legend of the figure, the results, or conclusions reported in the manuscript. The authors apologize for the error, and regret any inconvenience this may have caused.

Open Access This article is licensed under a Creative Commons Attribution-NonCommercial-NoDerivatives 4.0 International License, which permits any non-commercial use, sharing, distribution and reproduction in any medium or format, as long as you give appropriate credit to the original author(s) and the source, and provide a link to the Creative Commons license. You do not have permission under this license to share adapted material derived from this article or parts of it. The images or other third party material in this article are included in the article's Creative Commons license, unless indicated otherwise in a credit line to the material. If material is not included in the article's Creative Commons license and your intended use is not permitted by statutory regulation or exceeds the permitted use, you will need to obtain permission directly from the copyright holder. To view a copy of this license, visit http://creativecommons.org/licenses/by-nc-nd/4.0/.

\section{Esteller}

mesteller@iconcologia.net

1 Cancer Epigenetics and Biology Program (PEBC), Bellvitge Biomedical Research Institute (IDIBELL), 08907 L'Hospitalet, Barcelona, Spain

2 Experimental Therapeutics \& Cancer Genetics, MD Anderson Cancer Center, Texas State University, Houston, TX, USA

3 Department of Molecular Virology, Immunology and Medical Genetics, Comprehensive Cancer Center, The Ohio State University, Columbus, OH, USA

4 Institucio Catalana de Recerca i Estudis Avançats (ICREA), Barcelona, Catalonia, Spain 


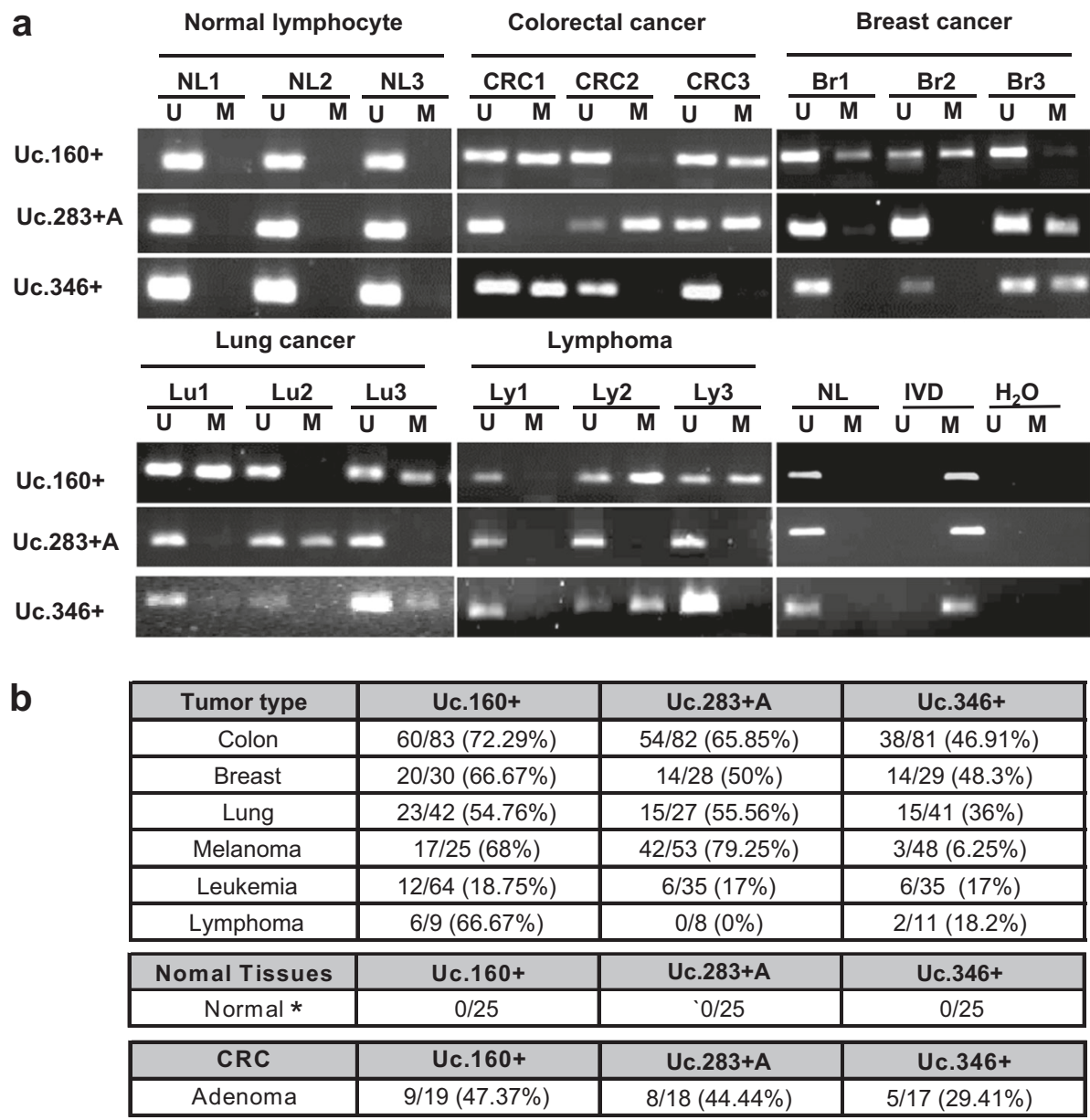

* 3 Normal lymphocyte; 5 normal colon, 2 normal breast and 15 normal lung were analyzed.

c

\begin{tabular}{|c|c|c|}
\hline Uc.160+ & Metastatic & Non metastatic \\
\hline Methylated cases & $\begin{array}{c}30 \text { of } 42 \\
(71.43 \%)\end{array}$ & $\begin{array}{c}30 \text { of } 55 \\
(54.54 \%)\end{array}$ \\
\hline P & \multicolumn{2}{|c|}{0.009322377} \\
\hline (Fisher's test) & \multicolumn{2}{|c|}{} \\
\hline
\end{tabular}

\begin{tabular}{|c|c|c|}
\hline Uc. 283+A & Metastatic & Non metastatic \\
\hline Methylated cases & $\begin{array}{c}22 \text { of } 31 \\
(70.97 \%)\end{array}$ & $\begin{array}{c}49 \text { of } 77 \\
(63.63 \%)\end{array}$ \\
\hline $\begin{array}{c}\text { P } \\
\text { (Fisher's test) }\end{array}$ & \multicolumn{2}{|c|}{$1.366 \mathrm{E}-07$} \\
\hline
\end{tabular}

\begin{tabular}{|c|c|c|}
\hline Uc.346+ & Metastatic & Non metastatic \\
\hline Methylated cases & $\begin{array}{c}18 \text { of } 41 \\
(43.90 \%)\end{array}$ & $\begin{array}{c}14 \text { of } 77 \\
(18.18 \%)\end{array}$ \\
\hline $\begin{array}{c}\text { P } \\
\text { (Fisher's test) }\end{array}$ & \multicolumn{2}{|c|}{$2.582 \mathrm{E}-07$} \\
\hline
\end{tabular}

d

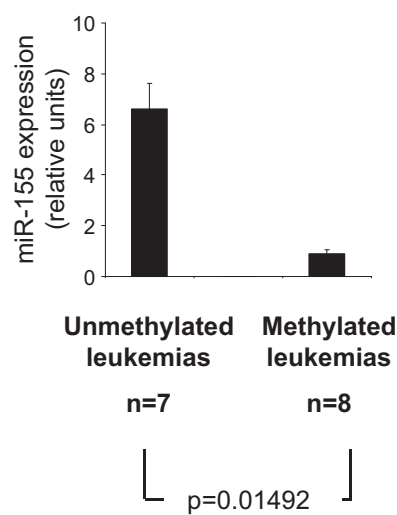

Fig. 1 ...... 